\title{
Effect of Nitrogen Management and Biofertilizers on Growth and Yield of Rapeseed (Brassica campestris var. toria)
}

\author{
Lakhan Bharti Saini*, P.J. George and Swai Singh Bhadana
}

Department of Agronomy, Naini Agricultural Institute, Sam Higginbottom University of Agricultural, Technology and Sciences (Formerly Allahabad Agricultural Institute), Allahabad - 211007 Uttar Pradesh, India

*Corresponding author

\section{A B S T R A C T}

\begin{tabular}{|c|c|}
\hline Keywords & $\begin{array}{l}\text { A field experiment was conducted during Rabi season, } 2016 \text { at the Crop Research Farm, } \\
\text { Department of Agronomy, SHUATS, and Allahabad (U.P.) to study the Effect of }\end{array}$ \\
\hline $\begin{array}{l}\text { Rapeseed, } \\
\text { Azotobacter, } \\
\text { Phosphate } \\
\text { solubilizing } \\
\text { bacterium (PSB), } \\
\text { Nitrogen } \\
\text { management, } \\
\text { Poultry manure. }\end{array}$ & $\begin{array}{l}\text { Biofertilizers and Nitrogen Management on Growth and Yield of Rapeseed (Brassica } \\
\text { campestris var. toria) in Randomized Block Design with Nine treatments replicated thrice. } \\
\text { The results showed under treatment } \mathrm{T}_{9} \text { (Azotobacter }+\mathrm{PSB}+30 \mathrm{~kg} \mathrm{ha}^{-1} \mathrm{~N} \text { through } \\
\text { inorganic Fertilizer }+30 \mathrm{~kg} \mathrm{ha}^{-1} \mathrm{~N} \text { through Organic manure poultry manure }(\mathrm{PM}) \text { produced } \\
\text { significantly higher plant height } 75 \text { Days }(95.53 \mathrm{~cm}) \text {, number of branch plant }{ }^{-1}(8.37) \text {, dry } \\
\text { weight }\left(15.58 \mathrm{~g} \text { ). The significantly higher yield under treatment } \mathrm{T}_{9} \text { (Azotobacter }+\mathrm{PSB}+\right. \\
30 \mathrm{~kg} \mathrm{ha}^{-1} \mathrm{~N} \text { through inorganic Fertilizer }+30 \mathrm{~kg} \mathrm{ha}^{-1} \mathrm{~N} \text { through poultry manure }(\mathrm{PM}) \text { ) } \\
\text { with No. of siliqua plant }{ }^{-1}(235.33) \text {, No. of seed siliqua plant }{ }^{-1}(20.40) \text {, Test Weight }(4.17\end{array}$ \\
\hline Article Info & $\begin{array}{l}\text { g), seed yield }\left(1500 \mathrm{~kg} \mathrm{ha}^{-1}\right) \text {, Stover yield }\left(3790 \mathrm{~kg} \mathrm{ha}^{-1}\right) \text {, harvest index }(28.36 \%) \text { and oil } \\
\text { content }(42.03 \%) \text { was recorded in treatment } \mathrm{T}_{9}\left(\text { Azotobacter }+\mathrm{PSB}+30 \mathrm{~kg} \mathrm{ha}^{-1} \mathrm{~N} \text { through }\right.\end{array}$ \\
\hline $\begin{array}{l}\text { Accepted: } \\
\text { 21 June } 2017 \\
\text { Available Online: } \\
10 \text { August } 2017\end{array}$ & $\begin{array}{l}\text { inorganic Fertilizer }+30 \mathrm{~kg} \mathrm{ha}^{-1} \mathrm{~N} \text { through poultry manure }(\mathrm{PM}) \text {. Treatment } \mathrm{T}_{9} \\
\left(\text { Azotobacter }+\mathrm{PSB}+30 \mathrm{~kg} \mathrm{ha}^{-1} \mathrm{~N} \text { through inorganic Fertilizer }+30 \mathrm{~kg} \mathrm{ha}^{-1} \mathrm{~N} \text { through }\right. \\
\text { poultry manure }(\mathrm{PM}) \text { also recorded the highest gross return }\left(67740 ₹ \mathrm{ha}^{-1}\right) \text {, net return } \\
\left(33265 ₹ \mathrm{ha}^{-1}\right) \text { and benefit cost ratio }(1.96) \text {. }\end{array}$ \\
\hline
\end{tabular}

\section{Introduction}

Rapeseed (Brassica campestris var. toria) commonly known as raya, rai or lahi is an important oilseed crop among the Brassica group of oilseed in India. It's the second most important edible oilseed crop in India after groundnut and accounts for nearly $30 \%$ of the total oilseeds produced in the country. Rapeseed-mustard is an important group of edible oil seed crops and contributes around $26.1 \%$ of the total oil seed production and contributes about $85 \%$ of the total rapeseedmustard produced in India (Meena et al., 2011). The first position in area and second position in Production after China (Anonymous, 2009). Rapeseed and mustard crops are being cultivated in 53 countries spreading over the six continents across the globe covering an area of 24.2 million hectare. Indians contribution to world hectare and production is 28.3 and 19.8 percent respectively.

In India, Toria is cultivated on 6.86 million hectares in Rabi season. Rapeseed-Mustard is the most important oil seed crop accounting around production 6.31(million tonnes) of 
total oilseed production in India (Directorate of Economics and Statistics, Department of Agriculture 2015). Nitrogen is the most important nutrient, which determines the growth of the mustard crop and increases the amount of protein and the yield.

Phosphorus and potash are known to be efficiently utilized in the presence of nitrogen. It promotes flowering, setting of siliqua and in increase the size of siliqua and yield (Bharose et al., 2010). Poultry manure is relaitively resistant to microbial degradation.

However it is essential for establishing and maintaining the optimum soil physical condition for plant growth. Poultry manure is also very cheap and effective as a good source of $\mathrm{N}$ for sustainable crop production, but its availability remains an important issue due to its bulky nature, while inorganic fertilizer is no longer within the reach of resource-poor farmers due to its high cost (Rahman, 2004).

Azotobactor is nonsymbiotic nitrogen fixing agro- microbe having potential to fix considerable quantities of atmospheric nitrogen in the rhizosphere of non-legumes.

Besides nitrogen fixation, Azotobactor synthesizes various growth promoting substances such as vitamins of B group, nicotinic acid, biotic, gibberellins and antifungal compounds. Azotobactor inoculation an improved the crop productivity $0-25 \%$ over the control in the absence of any amendment and by $8.75 \%$ in the presence of NPK (Narula, 2000).

Seed treatment, seedling dipping and soil application methods are used for Azotobacter application. For seed treatment $200 \mathrm{~g}$ Azotobacter used for $10 \mathrm{~kg}$ seed. Phosphate solubilizing bacterium (PSB) has a capacity to render the insoluble soil phosphorus into plant available form because of their ability to secrete various organic acids (Ram et al., 1999 and Gautam and Pant 2002).

\section{Materials and Methods}

A field Experiment was conducted on research farm of department of Agronomy Naini Agricultural Institute, Sam Higginbottom University of Agricultural, Technology and Sciences Allahabad, (U.P.), which is located at 25024 ' 42" N latitude, 810 50' 56" E longitude and $98 \mathrm{~m}$ altitude above the mean sea level. The soil was sandy loam in texture having $\mathrm{pH}$ (7.80), low in soluble salt $\left(0.13 \mathrm{dSm}^{-1}\right)$, organic carbon $(0.33 \%)$, available $\mathrm{P}_{2} \mathrm{O}_{5}\left(8.0 \mathrm{~kg} \mathrm{ha}^{-1}\right)$ and $\mathrm{K}_{2} \mathrm{O}(228.0$ $\mathrm{kg} \mathrm{ha}^{-1}$ ), respectively.

The experiments were laid out in randomized block design (RBD) with three replications on a plot size of $4.0 \times 2.5 \mathrm{~m}$.

The design applied for statistical analysis was carried out with randomized block design having two factors with Integrated Nitrogen management (INM) and Biofertilizers.

The treatment consisted of nine combination sources of Nitrogen inorganic fertilizers and poultry manure respectively. Biofertilizers are used Azotobacter and Phosphate solubilizing bacterium (PSB) $(200 \mathrm{~g} / 10 \mathrm{~kg}$ seed) for seed treatment. $\mathrm{T}_{1}$ (Azotobacter $+60 \mathrm{~kg} \mathrm{ha}^{-1} \mathrm{~N}$ inorganic Fertilizer), $\mathrm{T}_{2}$ (Azotobacter $+45 \mathrm{~kg}$ $\mathrm{ha}^{-1} \mathrm{~N}$ inorganic Fertilizer $+15 \mathrm{~kg} \mathrm{ha}^{-1} \mathrm{~N}$ poultry manure), $\mathrm{T}_{3}$ (Azotobacter $+30 \mathrm{~kg} \mathrm{ha}^{-1}$ $\mathrm{N}$ inorganic Fertilizer $+30 \mathrm{~kg} \mathrm{ha}^{-1} \mathrm{~N}$ poultry manure), $\mathrm{T}_{4}$

$\left(\mathrm{PSB}+60 \mathrm{~kg} \mathrm{ha}^{-1} \mathrm{~N}\right.$ inorganic Fertilizer), $\mathrm{T}_{5}$ $\left(\mathrm{PSB}+45 \mathrm{~kg} \mathrm{ha}^{-1} \mathrm{~N}\right.$ inorganic Fertilizer +15 $\mathrm{kg} \mathrm{ha}{ }^{-1} \mathrm{~N}$ poultry manure), $\mathrm{T}_{6}(\mathrm{PSB}+30 \mathrm{~kg}$ ha $^{-1} \mathrm{~N}$ inorganic Fertilizer $+30 \mathrm{~kg} \mathrm{ha}^{-1} \mathrm{~N}$ poultry manure), $\mathrm{T}_{7}$ (Azotobacter $+\mathrm{PSB}+60$ $\mathrm{kg} \mathrm{ha}^{-1} \mathrm{~N}$ inorganic Fertilizer), $\mathrm{T}_{8}$ (Azotobacter $+\mathrm{PSB}+45 \mathrm{~kg} \mathrm{ha}^{-1} \mathrm{~N}$ inorganic 
Fertilizer $+15 \mathrm{~kg} \mathrm{ha}^{-1} \mathrm{~N}$ poultry manure), $\mathrm{T}_{9}$ (Azotobacter $+\mathrm{PSB}+30 \mathrm{~kg} \mathrm{ha}^{1} \mathrm{~N}$ inorganic Fertilizer $+30 \mathrm{~kg} \mathrm{ha}^{-1} \mathrm{~N}$ poultry manure), having the treatments was replicated thrice. Nutrient management through Urea, SSP and $\mathrm{MoP}$ and organic nutrients sources as Poultry manure respectively to supply the required NPK The source.

Basal dose of fertilizer was applied in respective plots according to treatment allocation unfurrows opened by about $5 \mathrm{~cm}$. depth before sowing seeds in soil at the same time sowing of seeds was shown on well prepared beds in shallow furrows, at the depth of $5 \mathrm{~cm}$, row to row distance was maintained at $30 \mathrm{~cm}$ and plant to plant distance was $10 \mathrm{~cm}$, during the course of experiment, To record the various yield observations on rapeseed, a sample consisting of ten plants were selected at random observations were recorded as mean values of the data.

\section{Results and Discussion}

\section{Growth parameters}

The data presented in table 1 clearly shows that the plant height increased with the age of plants and it was maximum at 75 DAS.

The maximum plant height, number of branches per plant, dry weight per plant was significant increase at $75 \mathrm{DAS}$, the maximum plant height of $95.53 \mathrm{~cm}$, number of branches per plant 8.37 , dry weight $(\mathrm{g}) 15.58$ was recorded in $\mathrm{T}_{9}$ (Azotobacter $+\mathrm{PSB}+30 \mathrm{~kg}$ $\mathrm{ha}^{-1} \mathrm{~N}$ inorganic Fertilizer $+30 \mathrm{~kg} \mathrm{ha}^{-1} \mathrm{~N}$ poultry manure) which was significantly higher than other treatment. The minimum plant height was $89.80 \mathrm{~cm}$, number of branches per plant 7.07, dry weight (g) per plant 10.45 was recorded in $\mathrm{T}_{7}$ (Azotobacter + $60 \mathrm{~kg} \mathrm{ha}^{-1} \mathrm{~N}$ inorganic fertilizer (control)) at 75 DAS respectively. Similar results have also been recorded by Tetarwal and Rana
(2006) and Singh and Singh (2006).

\section{Yield attributes and oil quality of mustard}

The results of yield attributes and oil quality of seeds given in table 2 indicate some of the important parameters of number of siliqua plant $^{-1}$, number of seed siliqua ${ }^{-1}$, test weight (g) of seeds, seed yield, straw yield, harvest index, oil content of seeds of mustard crop increased significantly.

The factor of INM and Biofertilizers effect on number of siliqua plant ${ }^{-1}$, number of seed siliqua $^{-1}$, test weight of seeds, seed yield, straw yield, harvest index, oil content of seeds was significantly increased due to combined use of inorganic fertilizers, poultry manure and biofertilizer.

The maximum number of siliqua plant ${ }^{-1}$ 235.33 was non-significantly and number of seed siliqua ${ }^{1} 20.40$, test weight of seeds 4.17 $\mathrm{g}$, seed yield $1500 \mathrm{~kg} \mathrm{ha}^{-1}$, straw yield 3790 $\mathrm{kg} \mathrm{ha}^{-1}$, harvest index (\%) 28.36, oil content $42.03 \%$ was recorded in $\mathrm{T}_{9}$ (Azotobacter + PSB $+30 \mathrm{~kg} \mathrm{ha}^{-1} \mathrm{~N}$ inorganic Fertilizer +30 $\mathrm{kg} \mathrm{ha} \mathrm{h}^{-1} \mathrm{~N}$ poultry manure), which was significantly higher than other treatment Meena et al., (2013).

The minimum number of siliqua plant ${ }^{-1}$ 187.33 was non-significantly and number of seed siliqua ${ }^{1} 15.87$, test weight of seeds 3.51 $\mathrm{g}$, seed yield $926 \mathrm{~kg} \mathrm{ha}^{-1}$, straw yield $2886 \mathrm{~kg}$ $\mathrm{ha}^{-1}$, harvest index (\%) 24.29, oil content (\%) 34.87, was recorded in $\mathrm{T}_{7}$ (Azotobacter +60 $\mathrm{kg} \mathrm{ha}^{-1} \mathrm{~N}$ inorganic fertilizer (control)) at 75 DAS respectively.

Among the different treatments studied with respect of maximum $\mathrm{B}: \mathrm{C}$ ratio, The maximum $\mathrm{B}: \mathrm{C}$ ratio was recorded (1.96) in $\mathrm{T}_{9}$ and the minimum was recorded in $\mathrm{T}_{1}$ (1.36).Similar results were reported by Rundala et al., (2013), Tripathi et al., (2011), Das and Sinha (2014) and Singh and Pal (2011). 
Table.1 Plant growth parameter

\begin{tabular}{|c|c|c|c|c|}
\hline & Treatments & Plant height $^{-1}$ & Branches plant $^{-1}$ & Dry weight (g) \\
\hline $\mathrm{T}_{1}$ & Azoto. $+60 \mathrm{~kg} \mathrm{ha}^{-1} \mathrm{~N}$ through inorganic Fertilizer & 89.80 & 7.07 & 10.45 \\
\hline $\mathrm{T}_{2}$ & Azoto. $+45 \mathrm{~kg} \mathrm{ha}^{-1} \mathrm{~N}$ through inorganic Fertilizer $+15 \mathrm{~kg} \mathrm{ha}^{-1} \mathrm{~N}$ through $(\mathrm{PM})$ & 91.33 & 7.27 & 12.60 \\
\hline $\mathrm{T}_{3}$ & Azoto. $+30 \mathrm{~kg} \mathrm{ha}^{-1} \mathrm{~N}$ through inorganic Fertilizer $+30 \mathrm{~kg} \mathrm{ha}^{-1} \mathrm{~N}$ through $(\mathrm{PM})$ & & & \\
\hline & & 90.97 & 7.27 & 12.37 \\
\hline $\mathrm{T}_{4}$ & PSB $+60 \mathrm{~kg} \mathrm{ha}^{-1} \mathrm{~N}$ through inorganic Fertilizer & & & 12.27 \\
\hline $\mathrm{T}_{5}$ & $\mathrm{PSB}+45 \mathrm{~kg} \mathrm{ha}^{-1} \mathrm{~N}$ through inorganic Fertilizer $+15 \mathrm{~kg} \mathrm{ha}^{-1} \mathrm{~N}$ through $(\mathrm{PM})$ & 90.38 & 7.37 & 11.89 \\
\hline $\mathrm{T}_{6}$ & $\mathrm{PSB}+30 \mathrm{~kg} \mathrm{ha}^{-1} \mathrm{~N}$ through inorganic Fertilizer $+30 \mathrm{~kg} \mathrm{ha}^{-1} \mathrm{~N}$ through $(\mathrm{PM})$ & & & \\
\hline $\mathrm{T}_{7}$ & Azoto. + PSB $+60 \mathrm{~kg} \mathrm{ha}^{-1} \mathrm{~N}$ through inorganic Fertilizer & 92.15 & 7.37 & $\begin{array}{l}13.43 \\
14.26\end{array}$ \\
\hline & Azoto. + PSB $+45 \mathrm{~kg} \mathrm{ha}^{-1} \mathrm{~N}$ through inorganic Fertilizer $+15 \mathrm{~kg} \mathrm{ha}^{-1} \mathrm{~N}$ & 94.37 & 8.10 & \\
\hline $\mathrm{T}_{8}$ & through (PM) & & & 14.09 \\
\hline & Azoto. + PSB $+30 \mathrm{~kg} \mathrm{ha}^{-1} \mathrm{~N}$ through inorganic Fertilizer $+30 \mathrm{~kg} \mathrm{ha}^{-1} \mathrm{~N}$ & 93.89 & 7.90 & \\
\hline $\mathrm{T}_{9}$ & through (PM) & 95.53 & 8.37 & 15.58 \\
\hline & F- test & $\mathrm{S}$ & $\mathrm{S}$ & $\mathrm{S}$ \\
\hline & S. Ed. $( \pm)$ & 1.220 & 0.127 & 0.196 \\
\hline & C. D. $(P=0.05)$ & 2.517 & 0.261 & 0.404 \\
\hline
\end{tabular}

Azoto: Azotobacter, PSB: Phosphate-solubilizing bacteria, PM: poultry Manure. 
Table.2 Plant yield attributes parameter

\begin{tabular}{|c|c|c|c|c|c|c|c|c|c|}
\hline \multicolumn{2}{|c|}{ Treatments } & \multirow{2}{*}{$\begin{array}{c}\begin{array}{c}\text { Seeds } \\
\text { siliqua }^{-1}\end{array} \\
15.87\end{array}$} & \multirow{2}{*}{\begin{tabular}{|c|}
$\begin{array}{c}\text { Siliqua } \\
\text { plant }^{-1}\end{array}$ \\
187.33
\end{tabular}} & \multirow{2}{*}{$\begin{array}{c}\begin{array}{c}\text { Test weight } \\
\text { (g) }\end{array} \\
3.51\end{array}$} & \multirow{2}{*}{$\begin{array}{c}\begin{array}{c}\text { Grain yield (t } \\
\left.\mathbf{h a}^{-1}\right)\end{array} \\
926.67 \\
\end{array}$} & \multirow{2}{*}{$\begin{array}{c}\begin{array}{c}\text { Stover yield (t } \\
\text { ha }^{-1} \text { ) }\end{array} \\
2886.67\end{array}$} & \multirow{2}{*}{$\begin{array}{c}\text { Oil content (\%) } \\
34.87\end{array}$} & \multirow{2}{*}{$\begin{array}{c}\begin{array}{l}\text { Harvest Index } \\
(\%)\end{array} \\
24.29\end{array}$} & \multirow{2}{*}{\begin{tabular}{|r|}
$\begin{array}{l}\text { B:C } \\
\text { ratio }\end{array}$ \\
1.36 \\
\end{tabular}} \\
\hline $\mathrm{T} 1$ & Azoto. $+60 \mathrm{~kg} \mathrm{ha}^{-1} \mathrm{~N}$ through inorganic Fertilizer & & & & & & & & \\
\hline $\mathrm{T}_{2}$ & $\begin{array}{l}\text { Azoto. }+45 \mathrm{~kg} \mathrm{ha}^{-1} \mathrm{~N} \text { through inorganic Fertilizer }+15 \mathrm{~kg} \\
\mathrm{ha}^{-1} \mathrm{~N} \text { through }(\mathrm{PM})\end{array}$ & 16.40 & 224.00 & 3.74 & 1126.67 & 3130.00 & 35.93 & 26.39 & 1.55 \\
\hline T3 & $\begin{array}{l}\text { Azoto. }+30 \mathrm{~kg} \mathrm{ha}^{-1} \mathrm{~N} \text { through inorganic Fertilizer }+30 \mathrm{~kg} \\
\mathrm{ha}^{-1} \mathrm{~N} \text { through }(\mathrm{PM})\end{array}$ & 16.07 & 206.33 & 3.78 & 1116.67 & 3123.33 & 37.23 & 26.31 & 1.51 \\
\hline $\mathrm{T}_{4}$ & PSB $+60 \mathrm{~kg} \mathrm{ha}^{-1} \mathrm{~N}$ through inorganic Fertilizer & 16.51 & 195.67 & 3.68 & 1056.67 & 3046.67 & 36.23 & 25.76 & 1.51 \\
\hline T5 & $\begin{array}{l}\text { PSB }+45 \mathrm{~kg} \mathrm{ha}^{-1} \mathrm{~N} \text { through inorganic Fertilizer }+15 \mathrm{~kg} \text { ha } \\
{ }^{-1} \mathrm{~N} \text { through }(\mathrm{PM})\end{array}$ & 15.93 & 226.33 & 3.58 & 1053.33 & 2946.67 & 36.03 & 26.33 & 1.46 \\
\hline T6 & $\begin{array}{l}\text { PSB }+30 \mathrm{~kg} \mathrm{ha}^{-1} \mathrm{~N} \text { through inorganic Fertilizer }+30 \mathrm{~kg} \\
\mathrm{ha}^{-1} \mathrm{~N} \text { through }(\mathrm{PM})\end{array}$ & 17.20 & 225.33 & 3.89 & 1086.67 & 2900.00 & 37.17 & 27.27 & 1.45 \\
\hline $\mathrm{T}_{7}$ & Azoto. + PSB + $60 \mathrm{~kg} \mathrm{ha}^{-1} \mathrm{~N}$ through inorganic Fertilizer & 19.07 & 232.00 & 3.98 & 1326.67 & 3506.67 & 39.00 & 27.42 & 1.84 \\
\hline $\mathrm{T} 8$ & $\begin{array}{l}\text { Azoto. + PSB }+45 \mathrm{~kg} \mathrm{ha}^{-1} \mathrm{~N} \text { through inorganic } \\
\text { Fertilizer+ } 15 \mathrm{~kg} \mathrm{ha}^{-1} \mathrm{~N} \text { through }(\mathrm{PM})\end{array}$ & 17.87 & 229.33 & 3.97 & 1173.33 & 3326.67 & 38.77 & 26.08 & 1.63 \\
\hline T9 & $\begin{array}{l}\text { Azoto. + PSB }+30 \mathrm{~kg} \mathrm{ha}^{-1} \mathrm{~N} \text { through inorganic } \\
\text { Fertilizer+ } 30 \mathrm{~kg} \mathrm{ha}^{-1} \mathrm{~N} \text { through }(\mathrm{PM})\end{array}$ & 20.40 & 235.33 & 4.17 & 1500.00 & 3790.00 & 42.03 & 28.36 & 1.96 \\
\hline & F-test & $\mathrm{S}$ & $\mathrm{S}$ & $\mathrm{S}$ & $\mathrm{S}$ & $\mathrm{S}$ & $\mathrm{S}$ & $\mathrm{S}$ & \\
\hline & S.Ed. $( \pm)$ & 0.973 & 1.655 & 0.084 & 73.678 & 101.735 & 1.125 & 0.963 & \\
\hline & C. D. $(P=0.05)$ & 2.009 & 3.415 & 0.174 & 152.071 & 209.98 & 2.321 & 1.988 & \\
\hline
\end{tabular}


It is concluded that the best yield attributes characters in treatment $\mathrm{T}_{9}$ in respect to different day's intervals. The highest plant height $(95.53 \mathrm{~cm})$, number of branches $(8.37)$, dry weight plant $^{-1}(15.58 \mathrm{~g})$ were recorded in treatment $\mathrm{T}_{9}$ (Azotobacter $+\mathrm{PSB}+30 \mathrm{~kg} \mathrm{ha}^{-1}$ $\mathrm{N}$ through inorganic Fertilizer $+30 \mathrm{~kg} \mathrm{ha}^{-1} \mathrm{~N}$ through poultry Manure (PM).Growth and yield, treatment $\mathrm{T}_{9}$ (Azotobacter $+\mathrm{PSB}+30$ $\mathrm{kg} \mathrm{ha}^{-1} \mathrm{~N}$ through inorganic Fertilizer $+30 \mathrm{~kg}$ $\mathrm{ha}^{-1} \mathrm{~N}$ through poultry Manure (PM) produced highest Number of siliqua plant ${ }^{-1}$ (235.33), Number of seed siliqua ${ }^{-1}$ (20.40), seed Test weight $(4.17 \mathrm{~g})$, seed yield $(1500 \mathrm{~kg}$ $\left.\mathrm{ha}^{-1}\right)$, Stover yield (3790 kg ha $\left.{ }^{-1}\right)$, harvest index $(28.36 \%)$, and oil content $(42.03 \%)$ respectively. Treatment T9 (Azotobacter + PSB + $30 \mathrm{~kg} \mathrm{ha}^{-1} \mathrm{~N}$ through inorganic Fertilizer $+30 \mathrm{~kg} \mathrm{ha}^{-1} \mathrm{~N}$ through poultry Manure (PM)) also recorded the highest gross return $\left(67740 ₹\right.$ ha $\left.^{-1}\right)$, net return $(33264.2 ₹$ $\mathrm{ha}^{-1}$ ) and benefit cost ratio (1.96). It may be concluded that among the combination of $\mathrm{T}_{9}$ (Azotobacter + PSB $+30 \mathrm{~kg} \mathrm{ha}^{-1} \mathrm{~N}$ through inorganic Fertilizer $+30 \mathrm{~kg} \mathrm{ha}^{-1} \mathrm{~N}$ through poultry Manure (PM) was found to be best for obtaining the highest seed yield, oil content in Rapeseed var. Toria.

Since, the finding is based on the research done in one season it may be repeated for confirmation.

\section{References}

Anonymous (2009-10) Economic survey, Ministry of Finance, Government of India.

Directorate of Economics and Statistics, Department of Agriculture 2015.

DE B., Das B., Das B. and Sinha A. C. (2014) Effect of integrated nutrient management on yield, nutrient uptake and economics of rapeseed (Brassica campestris var. yellow sarson) in terai region of West Bengal. Journal of Crop and Weed; 10(1):69-72.

Gautam, P. and Pant, L. M. (2002) Effect of coinoculation of Pseudomonas species and Brady rhizobium japonicum on nitrogen and phosphorus availability to soybean (Glycine max). Indian J. Agric. Sci., 72(4): 248-251.

Meena, P.D., Chattopadhyay, C., Kumar, K., Awasthi, R.P., Singh, R., Kaur, S., Thomas, L., Goyal, P. and Chand. P. 2011. Comparative study on the effect of chemicals on Alternaria blight in Indian mustard - A multi-location study in India. J.Environ.Biol.32, 375-379.

Meena, D.S., Meena, V.R .and Meena, A.K., (2013) Fertilizer management studies on growth and productivity of hybrid Indian mustard Brassica juncea (L.) Journal of oilseed Brassica, 4(1); 39-42

Ram bharose, Chandra, S., Thomas, T. and Dhan, D. (2010) Effect of different levels of phosphorus and sulphur on yield and availability of NPK protein and oil content in Tpria. (Brassica sp.) CV. P.T.-303.ARPN Journal of Agricultural and Biological Science. Vol 6, No 2.

Rahman SA (2004). The Place of Organic Manure in Sustaining Agricultural Development in Nigeria. Paper presented at Science Technology and Society National Workshop in Lafia, Nasarawa State, 2004.

Rundala, S. R., Kumawat, B. L., Choudhary, G. L., Prajapat, K., K. Sita (2013) Performance of Indian mustard (Brassica juncea) under integrated nutrient management. Crop Research (Hisar); 46(1/3):115-118.

Tripathi M. K., Chaturvedi, S. Shukla, D. K. Saini, S. K. (2011)Influence of integrated nutrient management on growth, yield and quality of Indian mustard (Brassica juncea L.) in tarai region of northern India. Journal of Crop and Weed; 7(2):104-107. 
Singh R. and Singh S. K. (2006) Evaluation of yield and quality aspects of Indian mustard (Brassica juncea L. Czernj and Cosson) under integrated nutrient management. Annals of Agricultural Research; 27(3):220-223.

Singh, S. P. and Pal, M. S. (2011) Effect of integrated nutrient management on productivity, quality, nutrient uptake and economics of mustard (Brassica juncea). Indian Journal of Agronomy; 56(4):381-387.

Tripathi M. K., Chaturvedi, S. Shukla, D. K. Saini, S. K. (2011) Influence of integrated nutrient management on growth, yield and quality of Indian mustard (Brassic juncea L.) in tarai region of northern India. Journal of Crop and Weed; 7(2):104-107.

\section{How to cite this article:}

Lakhan Bharti Saini, P.J. George and Swai Singh Bhadana. 2017. Effect of Nitrogen Management and Biofertilizers on Growth and Yield of Rapeseed (Brassica campestris var. toria). Int.J.Curr.Microbiol.App.Sci. 6(8): 2652-2658.

doi: https://doi.org/10.20546/ijcmas.2017.608.316 